\title{
Influence of body length on orthostatic test parameters of student- athletes
}

\author{
Borysenko I.V. ${ }^{1}$, Cretu Marian², Kozina Zh.L. ${ }^{1}$ \\ ${ }^{1}$ H.S. Skovoroda Kharkiv National Pedagogical University, Ukraine \\ ${ }^{2}$ Faculty of Science, Physical Education and Informatics; University of Pitesti, Romania
}

DOI: https://doi.org/10.34142/HSR.2020.06.04.05

\section{How to Cite}

Borysenko I.V., Cretu Marian, Kozina Zh.L. Influence of body length on orthostatic test parameters of studentathletes. Health, Sport, Rehabilitation. 2020;6(4):47-57. https://doi.org/10.34142/HSR.2020.06.04.05

\begin{abstract}
Aim: to identify the influence of body length on the indicators of vegetative-vascular regulation of student-athletes. Material and methods. The study involved 42 second-year students who play sports at the amateur level (qualification level - 2-3 sports degree). The following research methods were used in the work: method of analysis of literary sources; method of determining body length; orthostatic test method; method of determining stroke volume and minute blood volume.

Results. It was found that the increase in systolic blood pressure during the transition from horizontal to vertical position in students whose body length is above 190, significantly higher than in students whose body length does not exceed $175 \mathrm{~cm}(\mathrm{p}<0.01)$ diastolic blood pressure, then in students whose body length is above $190 \mathrm{~cm}$, this figure is significantly higher $(p<0.01$ ) both horizontally and vertically. The stroke volume of tall (more than $190 \mathrm{~cm}$ body length) students in the standing position is significantly less than that of students with a body length of $150-175 \mathrm{~cm}$. There is a significant effect of body length on systolic blood pressure in the standing position, diastolic blood pressure in the supine and standing positions, heart rate in the supine and standing positions, stroke volume in the standing position, minute blood volume in the supine position and standing $(p<0,001)$. The effect of body length on the orthostatic test was also significant for the following data: systolic blood pressure in the vertical position, diastolic blood pressure in the vertical position; change in diastolic blood pressure when changing body position from horizontal to vertical; heart rate in vertical and horizontal positions; change in heart rate during the transition from horizontal to vertical position; stroke volume of blood in the vertical position; change in stroke volume of blood during the transition from horizontal to vertical position; all indicators of minute blood volume.

Conclusions. The state of the cardiovascular system of student-athletes is characterized by high fitness. It was found that students with a body length of more than $190 \mathrm{~cm}$ have difficulty with vegetative-vascular regulation.
\end{abstract}

Key words: orthostatic test, body length, athletes 


\section{Анотація}

\section{Борисенко І.В., Козіна Ж.Л. Вплив довжини тіла на показники ортостатичної проби студентів-спортсменів}

Мета: виявити вплив довжини тіла на показники вегето-судинної регуляції студентів-спортсменів.

Матеріал і методи. В дослідженні взяли участь 42 студента 2-го курсу, які займаються спортом на любительському рівні (рівень кваліфікації - 2-3 спортивні розряди). В роботі застосовувались такі методи дослідження: метод аналізу літературних джерел; метод визначення довжини тіла; метод ортостатичної проби; метод визначення ударного об'єму крові та хвилинного об'єму крові.

Результати. Виявлено, що підвищення систолічного артеріального тиску при переході 3 горизонтального положення у вертикальне у студентів, довжина тіла яких вище 190, достовірно вище, ніж у студентів, довжина тіла яких не перевищує 175 см (p<0,01) діастолічного артеріального тиску, то у студентів, довжина тіла яких вище 190 см, цей показник достовірно вище $(p<0,01)$ як у горизонтальному положенні, так і у вертикальному. Ударний об'єм крові у високорослих (довжина тіла більше 190 см) студентів в положенні стоячи достовірно менше у порівнянні з цим показником студентів з довжиною тіла 150-175 см. Це ж саме стосується і хвилинного об'єму крові. Спостерігається достовірний вплив довжини тіла на показники систолічного артеріального тиску в положенні стоячи, діастолічного артеріального тиску в положенні лежачи і стоячи, на частоту серцевих скорочень в положеннях лежачи і стоячи, ударний об'єм крові в положенні стоячи, хвилинний об'єм крові в положеннях лежачи і стоячи $(p<0,001)$. Вплив довжини тіла на показники ортостатичної проби також виявився достовірним для наступних даних: систолічний артеріальний тиск у вертикальному положенні, діастолічний артеріальний тиск у вертикальному положенні; зміна діастолічного артеріального тиску при зміні положення тіла з горизонтального на вертикальне; частота серцевих скорочень у вертикальному та горизонтальному положеннях; зміна чСС при переході з горизонтального у вертикальне положення; ударний об'єм крові у вертикальному положенні; зміна ударного об'єму крові при переході з горизонтального у вертикальне положення; всі показники хвилинного об'єму крові.

Висновки. Стан серцево-судинної системи студентів-спортсменів характеризується високою тренованістю. Виявлено, що у студентів з довжиною тіла понад 190 см спостерігається утруднення вегето-судинної регуляції. Ключові слова: ортостатичний тест, довжина тіла, спортсмени

\section{Аннотация \\ Борисенко И.В., Крету М., Козина Ж.Л. Влияние длины тела на показатели ортостатической пробы студентов- спортсменов}

Цель: выявить влияние длины тела на показатели вегетативно-сосудистой регуляции студентов-спортсменов. Материал и методы. В исследовании приняли участие 42 студента 2 курса, занимающихся спортом на любительском уровне (квалификационный уровень - 2-3 спортивный разряд). В работе использованы следующие методы исследования: метод анализа литературных источников; метод определения длины тела; метод ортостатической пробы; метод определения ударного объема и минутного объема крови.

Результаты. Выявлено, что повышение систолического артериального давления при переходе из горизонтального положения в вертикальное у студентов, длина тела которых превышает 190, достоверно выше, чем у студентов, длина тела которых не превышает 175 см (p<0,01) диастолического артериального давления, то у студентов, длина тела которых превышает 190 см, этот показатель значительно выше $(p<0,01)$ как по горизонтали, так и по вертикали. Ударный объем студентов высокого роста (длина тела более 190 см) в положении стоя значительно меньше, чем у студентов с длиной тела 150-175 см. Существенное влияние длины тела на систолическое артериальное давление в положении стоя, диастолическое артериальное давление в положениях лежа и стоя, частоту сердечных сокращений в положениях лежа и стоя, ударный объем в положении стоя, минутный объем крови в положении лежа на спине. и стоя ( $p<0,001)$. Влияние длины тела на ортостатический тест также было значимым для следующих данных: систолическое артериальное давление в вертикальном положении, диастолическое артериальное давление в вертикальном положении; изменение диастолического артериального давления при изменении положения тела с горизонтального на вертикальное; пульс в вертикальном и горизонтальном положениях; изменение чСС при переходе из горизонтального положения в вертикальное; ударный объем крови в вертикальном положении; изменение ударного объема крови при переходе из горизонтального положения в вертикальное; все показатели минутного объема крови.

Выводы. Состояние сердечно-сосудистой системы студентов-спортсменов характеризуется высокой физической подготовкой. Выявлено, что студенты с длиной тела более 190 см испытывают трудности с вегето-сосудистой регуляцией.

Ключевые слова: ортостатическая проба, длина тела, спортсмены. 


\section{Introduction}

An important and urgent problem of the current stage of sports development is the preservation and strengthening of the health of young people in the process of sports activities. One way to assess the functional state of the cardiovascular system is to determine the level of orthostatic stability of the human body. Regardless of the sport and physical activity, the cause of sudden death in most cases is pathology of the cardiovascular system. Students with a body length greater than $190 \mathrm{~cm}$ have less adaptive capacity for vegetative-vascular regulation compared to students of medium and below average height.

The idea to use the change of body position in space to study the functional state of the organism has been implemented in the practice of functional diagnostics for a long time [1].

The orthostatic test provides important information primarily in those sports that are characterized by a change in body position in space (gymnastics, rhythmic gymnastics, acrobatics, trampoline jumping, diving, high jump and the sixth, and recently - and basketball) [2-3]. An important and urgent problem of the current stage of sports development is the preservation and strengthening of the health of young people in the process of sports activities [4-6]. One way to assess the functional state of the cardiovascular system is to determine the level of orthostatic stability of the human body. Regardless of the sport and physical activity, the cause of sudden death in most cases is pathology of the cardiovascular system. Students with a body length greater than 190 $\mathrm{cm}$ have less adaptive capacity for vegetativevascular regulation compared to students of medium and below average height.

The idea to use the change of body position in space to study the functional state of the organism has been implemented in the practice of functional diagnostics for a long time [1].

The orthostatic test provides important information primarily in those sports that are characterized by a change in body position in space (gymnastics, rhythmic gymnastics, acrobatics, trampoline jumping, diving, high jump and the sixth, and recently - and basketball ) [7-8]. In all these sports, orthostatic stability is a necessary condition for athletic performance. Usually under the influence of systematic training orthostatic stability increases.

Orthostatic reactions of the athlete's body are due to the fact that when the body transitions from a horizontal to a vertical position in its lower half, a significant amount of blood is deposited [9-11]. As a result, the venous return of blood to the heart deteriorates and blood emission is reduced. Compensation for this adverse effect is mainly due to increased heart rate. In addition, an important role belongs to the change of vascular tone [12-14].

The degree of reduction of venous return of blood to heart at change of position of a body to a greater extent depends on a tone of large veins. If it is reduced, the increase in venous return may be so significant that the transition to an upright position due to a sharp deterioration in the blood supply to the brain may develop unconsciousness [16-18]. Low venous tone can also cause unconsciousness during prolonged stay in an upright position - orthostatic collapse [19-20].

In athletes, orthostatic instability associated with decreased venous tone develops relatively rarely. However, when conducting orthostatic tests, it can sometimes be detected. Therefore, the use of orthostatic tests to assess the functional state of the body of athletes is considered appropriate.

Orthostatic collapse is rare in people engaged in physical culture and sports, but in tall people and asthenic physique orthostatic collapse is quite common. Because most basketball players and other sports, as well as some athletics, are tall and asthenic, the phenomenon of orthostatic collapse (also known as gravitational shock) is well understood. In conversations with athletes who found inadequate responses to orthostatic testing, it was found that they have orthostatic collapse is quite common in abrupt transitions from sitting or lying to standing [6-8]. In all these sports, orthostatic stability is a necessary condition for athletic performance. Usually under the influence of systematic training orthostatic stability increases.

Orthostatic reactions of the athlete's body are due to the fact that when the body transitions from a horizontal to a vertical position in its lower half, a significant amount of blood is deposited. As a result, the venous return of blood to the heart deteriorates and blood emission is reduced. Compensation for this adverse effect is mainly due to increased heart rate. In addition, an important role belongs to the change of vascular tone.

The degree of reduction of venous return of blood to heart at change of position of a body to a greater extent depends on a tone of large veins. If it is reduced, the increase in venous return may be so significant that the transition to an upright position due to a sharp deterioration in the blood supply to the brain may develop unconsciousness. Low venous tone can also cause unconsciousness during prolonged stay in an upright position - orthostatic collapse.

In athletes, orthostatic instability associated with decreased venous tone develops relatively 
rarely. However, when conducting orthostatic tests, it can sometimes be detected. Therefore, the use of orthostatic tests to assess the functional state of the body of athletes is considered appropriate.

Orthostatic collapse is rare in people engaged in physical culture and sports, but in tall people and asthenic physique orthostatic collapse is quite common [12-13]. Because most basketball players and other sports, as well as some athletics, are tall and asthenic, the phenomenon of orthostatic collapse (also known as gravitational shock) is well understood. In conversations with athletes who found inadequate responses to orthostatic testing, it was found that they have orthostatic collapse is quite common in abrupt transitions from sitting or lying to standing [6-8].

\section{Matherials and methods}

\section{Participants}

The study involved 42 students who play sports at the amateur level (skill level - 2-3 sports). The number of students with a body length of more than $190 \mathrm{~cm}$ was 12 people. The number of students whose body length was $150-175 \mathrm{~cm}$ was 30 people. There were no students with a body length of 176$189 \mathrm{~cm}$ in the study. This was the basis for the division of students into such groups according to body length, because it is known that large values of body length (over $190 \mathrm{~cm}$ ) negatively affect the adaptation of the cardiovascular system in the transition from horizontal to vertical position.

The study was conducted on the basis of Kharkiv National Pedagogical University named after GS Frying pans.

\section{Procedure}

The following research methods were used in the work: method of analysis of literature sources; method of determining body length; orthostatic test method; method of determining stroke volume and minute blood volume; methods of statistical data processing (comparison of averages by the Student's method, multivariate analysis of variance and correlation analysis).

An orthostatic test measures heart rate and blood pressure. These values are measured in a horizontal position, then repeat these measurements in the subject after actively getting up in a vertical position at the 10th minute.

A natural reaction to the orthostatic test is an increase in heart rate. As a result, the minute volume of blood is slightly reduced. In well-trained athletes, heart rate is relatively small and ranges from 5 to 15 beats per minute. In young athletes, the reaction may be more pronounced. Systolic blood pressure either remains unchanged or even decreases slightly (by 2$6 \mathrm{~mm} \mathrm{Hg}$ ); diastolic blood pressure naturally increases by $10-15 \%$ relative to its value in the horizontal position. If during a 10-minute study the systolic pressure approaches the initial values, the diastolic pressure remains elevated. Signs of orthostatic instability are a sharp drop in blood pressure and a very large increase in heart rate. [1]

Measurements of body length are performed in a standing position using a vertical height meter. The person stands on a wooden plane with his back to the vertical bar, touching her heels, buttocks, interscapular area with the shoulders set back (head not resting). The arms should be lowered along the torso, the abdomen - tightened, the heels - together, the socks - separately. The position of the head should be such that the upper edge of the earlobe and the lower edge of the orbit are in the same horizontal plane. The movable bar is attached to the head without pressure, but tightly.

The magnitude of the stroke volume depends on the force of the heart contraction and the amount of blood flowing to it during diastole through the veins. Stroke volume (SV) can be calculated by Starr's formula [1]:

The minute volume of blood (MBV) is determined by the stroke volume and heart rate, depending on the position of the human body, its sex, age, fitness, environmental conditions and many other factors.

Calculate the minute blood volume (MBV) according to the formula:

$\mathrm{MBV}=\mathrm{SV} \times$ heart rate.

\section{Statistical analysis}

For each indicator, the arithmetic mean, standard deviation $\mathrm{S}$ (standard deviation), error of the mean (m) and estimation of the probability of discrepancies of indicators by Student's t-test with the appropriate level of probability (p) for groups of students with body length above average (more 190 $\mathrm{cm}$ ) and average (below average 150-175 cm). Differences and relationships were considered reliable at a significance level of $p<0.05$.

Also, multivariate analysis of variance was used by applying a general linear model. The dependent values were heart rate, systolic and diastolic blood pressure, stroke volume and minute blood volume in horizontal and vertical positions, and the difference between these values in different body positions. The independent value was the length of the body. Body length of $150-175 \mathrm{~cm}$ was denoted 
by the number "1", body length over $190 \mathrm{~cm}$ was denoted by the number " 2 ". There were no students with body length values of $175-190 \mathrm{~cm}$ in the study.

Correlation analysis of orthostatic test parameters with body length indicators was used.

For statistical processing of the obtained data were used computer programs Microsoft Excel "Data Analysis" - 2013, SPSS - 17.

\section{Results}

Analysis of the response to the orthostatic test of student-athletes showed that, in general, the state of the cardiovascular system of student-athletes is characterized by high fitness. Thus, the heart rate at rest lying down in students of all studied groups by body length is $48.5-69.33$ beats per minute. Heart rate less than 54 beats $\cdot \mathrm{min}^{-1}$ indicate functional bradycardia of athletes, characteristic of a state of high fitness. Systolic blood pressure in the supine position was $105-115 \mathrm{~mm} \mathrm{Hg}$. Diastolic blood pressure was $66-79 \mathrm{~mm} \mathrm{Hg}$. These indicators indicate the normal functional state of student-athletes. At the transition to the vertical position, the increase in heart rate was 5-11.5 beats per minute for all study groups. This indicates an adequate adaptive response of the cardiovascular system to the transition from horizontal to vertical position.

But in different groups there is a different severity of adaptive reactions in terms of blood pressure and heart rate. Thus, when comparing students with different body lengths revealed significant differences in systolic blood pressure in students of the two groups (Table 1).

Comparative characteristics of orthostatic test indicators of student-athletes with different anthropometric data (body length)

\begin{tabular}{|c|c|c|c|c|c|c|c|}
\hline \multirow{2}{*}{ Indexes } & \multirow{2}{*}{$\begin{array}{l}\text { Body } \\
\text { length }\end{array}$} & \multicolumn{6}{|c|}{ Statistical indicators } \\
\hline & & $\mathrm{N}$ & $\bar{x}$ & $S$ & $\mathrm{~m}$ & $\mathrm{t}$ & $p$ \\
\hline \multirow{2}{*}{$\begin{array}{l}\text { Systolic pressure } \\
(\mathrm{mm} . \mathrm{Hg}) \text { in the } \\
\text { horizontal position }\end{array}$} & $>190$ & 12 & 113.50 & 1.57 & 0.45 & \multirow[t]{2}{*}{1.82} & \multirow[t]{2}{*}{0.077} \\
\hline & $150-175$ & 30 & 110.00 & 6.56 & 1.20 & & \\
\hline \multirow{2}{*}{$\begin{array}{l}\text { Systolic pressure } \\
(\mathrm{mm} . \mathrm{Hg}) \text { in the } \\
\text { vertical position }\end{array}$} & $>190$ & 12 & 131.00 & 1.04 & 0.30 & \multirow[t]{2}{*}{3.28} & \multirow[t]{2}{*}{0.002} \\
\hline & $150-175$ & 30 & 121.60 & 9.83 & 1.80 & & \\
\hline \multirow{2}{*}{$\begin{array}{c}\text { Systolic pressure } \\
(\mathrm{mmHg}) \\
\text { difference }\end{array}$} & $>190$ & 12 & 17.50 & 2.61 & 0.75 & \multirow[t]{2}{*}{2.75} & \multirow[t]{2}{*}{0.009} \\
\hline & $150-175$ & 30 & 11.60 & 7.21 & 1.32 & & \\
\hline \multirow{2}{*}{$\begin{array}{l}\text { Diastolic pressure } \\
\text { (mm.rt.st.) in the } \\
\text { horizontal position }\end{array}$} & $>190$ & 12 & 79.00 & 1.04 & 0.30 & \multirow[t]{2}{*}{2.72} & \multirow[t]{2}{*}{0.010} \\
\hline & $150-175$ & 30 & 70.80 & 10.34 & 1.89 & & \\
\hline \multirow{2}{*}{$\begin{array}{l}\text { Diastolic pressure } \\
\text { (mmHg.) in the } \\
\text { vertical position }\end{array}$} & $>190$ & 12 & 86.00 & 6.27 & 1.81 & \multirow[t]{2}{*}{3.15} & \multirow[t]{2}{*}{0.003} \\
\hline & $150-175$ & 30 & 76.20 & 9.97 & 1.82 & & \\
\hline \multirow{2}{*}{$\begin{array}{c}\text { Diastolic pressure } \\
\text { difference }\end{array}$} & $>190$ & 12 & 7.00 & 7.31 & 2.11 & \multirow[t]{2}{*}{-1.76} & \multirow[t]{2}{*}{0.085} \\
\hline & $150-175$ & 30 & 11.00 & 6.37 & 1.16 & & \\
\hline \multirow[t]{2}{*}{$\begin{array}{l}\text { Heart rate (beats / } \min \text { ) in } \\
\text { the vertical position }\end{array}$} & $>190$ & 12 & 59.00 & 13.58 & 3.92 & \multirow[t]{2}{*}{-0.42} & \multirow[t]{2}{*}{0.678} \\
\hline & $150-175$ & 30 & 60.60 & 10.14 & 1.85 & & \\
\hline \multirow[t]{2}{*}{$\begin{array}{l}\text { Heart rate (beats / } \min \text { ) in } \\
\text { the vertical position }\end{array}$} & $>190$ & 12 & 68.50 & 8.88 & 2.56 & \multirow[t]{2}{*}{0.54} & \multirow[t]{2}{*}{0.595} \\
\hline & $150-175$ & 30 & 67.00 & 7.90 & 1.44 & & \\
\hline \multirow[t]{2}{*}{$\begin{array}{l}\text { Heart rate (beats / } \mathrm{min} \text { ) } \\
\text { difference }\end{array}$} & $>190$ & 12 & 9.50 & 4.70 & 1.36 & \multirow[t]{2}{*}{0.97} & \multirow[t]{2}{*}{0.339} \\
\hline & $150-175$ & 30 & 8.40 & 2.62 & 0.48 & & \\
\hline \multirow[t]{2}{*}{$\begin{array}{l}\text { Stroke volume }(\mathrm{ml}) \text { in a } \\
\text { horizontal position }\end{array}$} & $>190$ & 12 & 57.85 & 1.93 & 0.56 & \multirow{2}{*}{-1.89} & \multirow{2}{*}{0.066} \\
\hline & $150-175$ & 30 & 64.82 & 12.64 & 2.31 & & \\
\hline
\end{tabular}




\begin{tabular}{|c|c|c|c|c|c|c|c|}
\hline \multirow[t]{2}{*}{$\begin{array}{l}\text { Stroke volume }(\mathrm{ml}) \text { in the } \\
\text { upright position }\end{array}$} & $>190$ & 12 & 58.90 & 7.42 & 2.14 & \multirow[t]{2}{*}{-2.67} & \multirow[t]{2}{*}{0.011} \\
\hline & $150-175$ & 30 & 64.98 & 6.38 & 1.16 & & \\
\hline \multirow[t]{2}{*}{$\begin{array}{l}\text { Stroke volume }(\mathrm{ml}) \\
\text { difference }\end{array}$} & $>190$ & 12 & 8.95 & 1.10 & 0.32 & \multirow{2}{*}{-2.01} & \multirow{2}{*}{0.051} \\
\hline & $150-175$ & 30 & 12.60 & 6.20 & 1.13 & & \\
\hline \multirow{2}{*}{$\begin{array}{l}\text { Minute blood volume (I/ } \\
\text { min) in a horizontal position }\end{array}$} & $>190$ & 12 & 3.44 & 0.90 & 0.26 & \multirow{2}{*}{-1.56} & \multirow{2}{*}{0.126} \\
\hline & $150-175$ & 30 & 3.91 & 0.88 & 0.16 & & \\
\hline \multirow[t]{2}{*}{$\begin{array}{l}\text { Minute blood volume (I / } \\
\text { min) in the upright position }\end{array}$} & $>190$ & 12 & 3.97 & 0.02 & 0.00 & \multirow{2}{*}{-2.74} & \multirow{2}{*}{0.009} \\
\hline & $150-175$ & 30 & 4.32 & 0.44 & 0.08 & & \\
\hline \multirow{2}{*}{$\begin{array}{c}\text { Minute blood volume } \\
\text { difference }\end{array}$} & $>190$ & 12 & 0.85 & 0.56 & 0.16 & \multirow{2}{*}{0.68} & \multirow{2}{*}{0.503} \\
\hline & $150-175$ & 30 & 0.71 & 0.61 & 0.11 & & \\
\hline \multirow[t]{2}{*}{ Body length } & $>190$ & 12 & 192.50 & 2.61 & 0.75 & \multirow{2}{*}{16.67} & \multirow{2}{*}{0.000} \\
\hline & $150-175$ & 30 & 165,20 & 5,40 & 0,99 & & \\
\hline
\end{tabular}

The increase in systolic blood pressure in students whose body length is above 190, significantly higher than in students whose body length does not exceed $175 \mathrm{~cm}(\mathrm{p}<0,01)$ (Table 1). With regard to diastolic blood pressure, in students whose body length is higher than $190 \mathrm{~cm}$, this figure is significantly higher $(\mathrm{p}<0.01)$ in both horizontal and vertical position (Table 1). Stroke volume of blood in tall (body length more than $190 \mathrm{~cm}$ ) students in the standing position is significantly less compared to this figure of students with a body length of 150$175 \mathrm{~cm}$. The same applies to the minute blood volume (Table 1).

Significantly lower values of stroke volume and minute blood volume in tall students compared to middle-aged students indicate a lack of adaptation to changes in body position in tall students compared to students with a body length of $150-175 \mathrm{~cm}$.

In tall students there is no significantly greater difference in heart rate when changing body position from horizontal to vertical compared with students of average and below average height, and the change in heart rate is within normal limits (Table 1). But a more pronounced increase in systolic and diastolic blood pressure in tall students compared with students of medium and below average height indicates the activation of mechanisms of adaptation to changes in body position. After all, it is known that in tall people, the change in performance during the transition from horizontal to vertical position of the body is more pronounced, because a larger volume of blood falls sharply to the lower extremities. This leads to the need for more pronounced adaptation mechanisms in terms of heart rate and blood pressure. But blood pressure, both systolic and diastolic, is significantly higher in tall students compared to others (Table 1). This fact can be regarded as a more pronounced adaptive response of students with a body length above $190 \mathrm{~cm}$ from the cardiovascular system and vegetative-vascular regulation. But these adaptive responses are not sufficient, as the values of stroke volume and minute blood volume in the upright position in tall students are significantly smaller than in students with a body length of $150-175 \mathrm{~cm}$.

To more accurately confirm the obtained results of the influence of body length on the orthostatic sample, a multivariate analysis of variance was performed using a general linear model (Table 2).

A significant effect of body length on most indicators of the orthostatic sample was found (Table 2). Analysis of variance confirmed the results of comparison of averages by Student's t-test. Body length significantly affects the indicators of vegetative-vascular regulation. There is a significant effect of body length on systolic blood pressure in the standing position, diastolic blood pressure in the supine and standing positions, heart rate in the supine and standing positions, stroke volume in the standing position, minute blood volume in the supine position and standing $(\mathrm{p}<0,001)$.

The influence of body length and sport on orthostatic test parameters was also significant for the following data: systolic blood pressure in the vertical position, diastolic blood pressure in the vertical position; change in diastolic blood pressure when changing body position from horizontal to vertical; heart rate in vertical and horizontal positions; change in heart rate during the transition from horizontal to vertical position; stroke volume of blood in the vertical position; change in stroke volume of blood during the transition from horizontal to vertical position; all indicators of minute blood volume ( $\mathrm{p}<0.005 ; \mathrm{p}<0.01 ; \mathrm{p}<0.001)$. 
Table 2

Indicators of multifactor variance analysis of body length on indicators of orthoprobe of students (multifactor tests)

\begin{tabular}{|c|c|c|c|c|c|c|}
\hline \multirow{2}{*}{ Effect } & & \multicolumn{5}{|c|}{ Multivariate Tests(c) } \\
\hline & & Value & $\mathrm{F}$ & Hypothesis df & Error df & Sig. \\
\hline \multirow{4}{*}{ Intercept } & Pillai's Trace & 1.000 & 1632000.000 & 2.000 & 36.000 & 0.000 \\
\hline & Wilks' Lambda & 0.000 & 1632000.000 & 2.000 & 36.000 & 0.000 \\
\hline & Hotelling's Trace & 90689.733 & 1632000.000 & 2.000 & 36.000 & 0.000 \\
\hline & Roy's Largest Root & 90689.733 & 1632000.000 & 2.000 & 36.000 & 0.000 \\
\hline \multirow{4}{*}{$\begin{array}{l}\text { Body length- } \\
\text { (groups } 1 \\
\text { and } 2 \text { ) }\end{array}$} & Pillai's Trace & 0.868 & $118.697 a$ & 2.000 & 36.000 & 0.000 \\
\hline & Wilks' Lambda & 0.132 & $118.697 a$ & 2.000 & 36.000 & 0.000 \\
\hline & Hotelling's Trace & 6.594 & $118.697 a$ & 2.000 & 36.000 & 0.000 \\
\hline & Roy's Largest Root & 6.594 & $118.697 a$ & 2.000 & 36.000 & 0.000 \\
\hline \multirow{4}{*}{$\begin{array}{c}\text { Body length- } \\
\text { of the all } \\
\text { groups }\end{array}$} & Pillai's Trace & 0.930 & $238.011 a$ & 2.000 & 36.000 & 0.000 \\
\hline & Wilks' Lambda & 0.070 & $238.011 a$ & 2.000 & 36.000 & 0.000 \\
\hline & Hotelling's Trace & 13.223 & $238.011 a$ & 2.000 & 36.000 & 0.000 \\
\hline & Roy's Largest Root & 13.223 & $238.011 a$ & 2.000 & 36.000 & 0.000 \\
\hline
\end{tabular}

Notes: a. Exact statistic

b. The statistic is an upper bound on $\mathrm{F}$ that yields a lower bound on the significance level

The results obtained by applying the method of comparison of averages and analysis of variance are also confirmed by the results of correlation analysis (Table 3).

Correlation matrix of orthostatic test and body length indicators of students-athletes

Table 3

\begin{tabular}{|c|c|c|c|c|c|c|c|c|c|c|c|c|c|c|c|c|c|}
\hline & Indexes & 1 & 2 & 3 & 4 & 5 & 6 & 7 & 8 & 9 & 10 & 11 & 12 & 13 & 14 & 15 & 16 \\
\hline 1 & $\begin{array}{l}\text { Systolic pressure } \\
(\mathrm{mm} . \mathrm{Hg}) \text { in the } \\
\text { horizontal position }\end{array}$ & 1,00 & & & & & & & & & & & & & & & \\
\hline 2 & $\begin{array}{l}\text { Systolic pressure } \\
(\mathrm{mm} . \mathrm{Hg}) \text { in the } \\
\text { vertical position }\end{array}$ & 0,69 & 1,00 & & & & & & & & & & & & & & \\
\hline 3 & $\begin{array}{l}\text { Systolic pressure } \\
\text { (mmHg) } \\
\text { difference }\end{array}$ & 0,10 & 0,79 & 1,00 & & & & & & & & & & & & & \\
\hline 4 & $\begin{array}{l}\text { Diastolic pressure } \\
\text { (mm.rt.st.) in the } \\
\text { horizontal position }\end{array}$ & $-0,03$ & 0,56 & 0,80 & 1,00 & & & & & & & & & & & & \\
\hline 5 & $\begin{array}{l}\text { Diastolic pressure } \\
\text { (mmHg.) in the } \\
\text { vertical position }\end{array}$ & 0,83 & 0,90 & 0,53 & 0,42 & 1,00 & & & & & & & & & & & \\
\hline 6 & $\begin{array}{l}\text { Diastolic pressure } \\
\text { difference }\end{array}$ & 0,11 & $-0,38$ & $-0,62$ & $-0,46$ & $-0,01$ & 1,00 & & & & & & & & & & \\
\hline 7 & $\begin{array}{l}\text { Heart rate (beats / min) } \\
\text { in the horisontal } \\
\text { position }\end{array}$ & 0,52 & 0,59 & 0,36 & 0,16 & 0,75 & 0,17 & 1,00 & & & & & & & & & \\
\hline 8 & $\begin{array}{l}\text { Heart rate (beats / min) } \\
\text { in the vertical position }\end{array}$ & 0,44 & 0,48 & 0,28 & $-0,03$ & 0,66 & 0,39 & 0,86 & 1,00 & & & & & & & & \\
\hline 9 & $\begin{array}{c}\text { Heart rate (beats / min) } \\
\text { difference }\end{array}$ & $-0,58$ & $-0,42$ & $-0,09$ & $-0,11$ & $-0,68$ & $-0,25$ & $-0,89$ & $-0,60$ & 1,00 & & & & & & & \\
\hline
\end{tabular}


10 Stroke volume $(\mathrm{ml})$ in a

$\begin{array}{lllllllllllll}\text { horizontal position } & 0,28 & -0,36 & -0,74 & -0,97 & -0,19 & 0,49 & -0,03 & 0,16 & -0,03 & 1,00\end{array}$

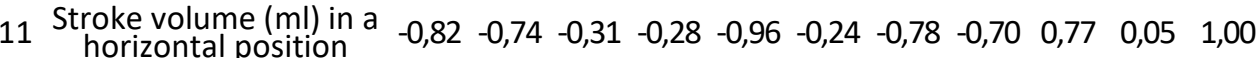

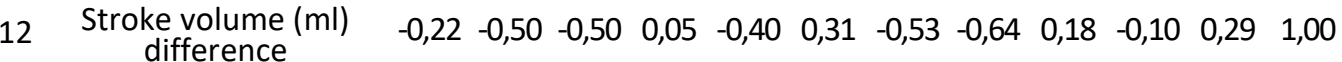

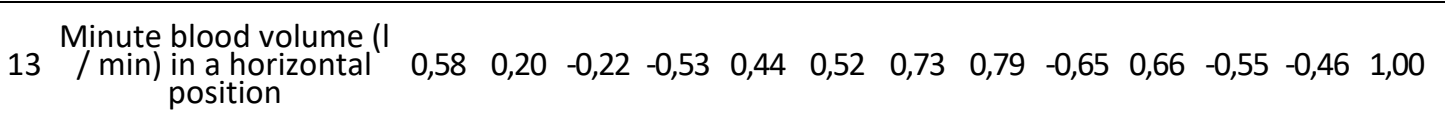

\author{
Minute blood volume (I

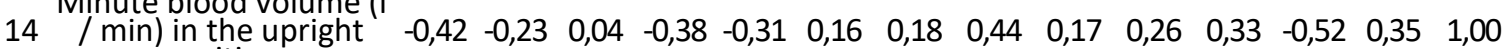 \\ position
}

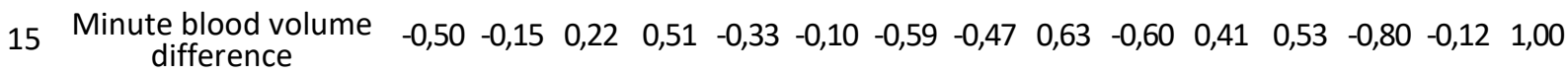

$16 \quad$ Body length $\quad \begin{array}{llllllllllllllllllllllll}0,50 & 0,71 & 0,55 & 0,49 & 0,72 & -0,20 & 0,24 & 0,35 & -0,11 & -0,32 & -0,65 & -0,40 & -0,02 & -0,37 & 0,01 & 1,00\end{array}$

Note: the critical value of the reliable correlation coefficient is equal to 0.5

There was a significant positive relationship between body length and heart rate in horizontal, vertical positions and changes in heart rate when changing body position from horizontal to vertical ( $\mathrm{r}$ $=0.50-0.71$ ) (Table 3). There was also a positive significant relationship between body length and the value of systolic pressure in the vertical position $(r=$ 0.72 ); negative significant relationship between body length and the value of the stroke volume of blood in the vertical position $(\mathrm{r}=-0.65)$ (Table 6). The obtained data also indicate the difficulty of adaptation to changes in the position of the body of tall students.

\section{Discussion}

The obtained data on the difficult vegetativevascular regulation of people whose body length is above average will be confirmed by the data (Kozina, Slyusarev, 2003; Khrust, 2006). These authors in the study of orthostatic reactions of basketball players found that many athletes do not respond adequately to changes in body position. Thus, tall basketball players showed a decrease in lower blood pressure during the transition from horizontal to vertical position. In some athletes, this decrease was so strong that there was an unconscious state, the so-called orthostatic collapse. In the literature (Osadchy, 1980) it is noted that orthostatic collapse is relatively rare in people engaged in physical culture and sports. It is noted, however, that in people of tall stature and asthenic physique, orthostatic collapse is a fairly common phenomenon. Since most basketball players have a tall stature and asthenic physique, the phenomenon of orthostatic collapse (another name gravitational shock) is quite clear to them. During the conversation of these authors with athletes who found an inadequate response to the orthostatic test, it was found that they have an orthostatic collapse is quite common in abrupt transitions from sitting or lying to standing.

Thus, we obtained results that confirm the results of the literature on the difficult vascular regulation of tall people. In addition, these results are clarified by the fact that a significant increase not only in diastolic blood pressure, but also systolic, in the transition from horizontal to vertical position. But these changes are insufficient for the adaptation to changes in body position in tall students was similar to students whose body length does not exceed the average.

Relatively new knowledge is also the more significant impact of judo and football compared to short and medium distance running on the indicators of vascular regulation: the best indicators - in judo, the next place - in football, then - athletes. It should be noted that students whose body length exceeded $190 \mathrm{~cm}$ were representatives of all these sports specializations, and therefore it can be assumed that body length did not affect the results of determining the sport on the orthostatic test.

It is known that the results of the orthostatic test are influenced by various factors: dehydration [9], periods of the training cycle [10], the level of training [11-13], the nature of the loads [14], bed rest [15]. The effect of orthostatic test on heart rate 
variability in young hockey players was also revealed [16]. In addition, various authors [17-21] have shown the effect on the orthostatic test of various functional states and diseases of the central nervous system. But the influence of athletes' body length on orthostatic test parameters before our study was insufficiently studied. Therefore, the results obtained by us have theoretical and practical significance.

Based on the results, the following recommendations can be made: to improve the adaptive capacity of vascular regulation to change body position from horizontal to vertical, it is effective to use any exercise, but the most effective exercises that activate aerobic and anaerobic glycolytic energy systems. In addition, exercises that require frequent transitions from lying down (sitting) to standing position, as well as changes in the direction of movement are useful.

The hypothesis presented in this study was confirmed in different ways as a result of the application of different methods of statistical data processing: comparison of averages by the Student's method, multivariate analysis of variance and correlation analysis. The applied methods of mathematical statistics allowed to draw similar conclusions. The results of a more significant impact of judo and football classes compared to short and medium distance running on the indicators of vascular regulation were obtained: the best indicators - in judo, the next place - in football, then - athletes. It was found that students with a body length of more than $190 \mathrm{~cm}$ have difficulty with vegetative-vascular regulation. To improve the adaptive capacity of vascular regulation to change the position of the body from horizontal to vertical is effective to use any exercise, but most effective exercises that activate aerobic and anaerobic glycolytic energy supply systems. In addition, exercises that require frequent transitions from lying down (sitting) to standing position, as well as changes in the direction of movement are useful.

\section{Conclusion}

1. It was found that the increase in systolic blood pressure during the transition from horizontal to vertical position in students whose body length is above 190, significantly higher than in students whose body length does not exceed $175 \mathrm{~cm}$ ( $p<0,01$ ) diastolic blood pressure, then in students whose body length is higher than $190 \mathrm{~cm}$, this figure is significantly higher $(\mathrm{p}<0.01)$ both horizontally and vertically. The stroke volume of tall (more than 190 $\mathrm{cm}$ body length) students in the standing position is significantly less than that of students with a body length of $150-175 \mathrm{~cm}$.

2. The results of analysis of variance confirmed the results of comparing the averages of the Student's t-test. It was found that body length significantly affects the indicators of vegetativevascular regulation. There is a significant effect of body length on systolic blood pressure in the standing position, diastolic blood pressure in the supine and standing positions, heart rate in the supine and standing positions, stroke volume in the standing position, minute blood volume in the supine position and standing $(\mathrm{p}<0,001)$. The effect of body length on the orthostatic test was also significant for the following data: systolic blood pressure in the vertical position, diastolic blood pressure in the vertical position; change in diastolic blood pressure when changing body position from horizontal to vertical; heart rate in vertical and horizontal positions; change in heart rate during the transition from horizontal to vertical position; stroke volume of blood in the vertical position; change in stroke volume of blood during the transition from horizontal to vertical position; all indicators of minute blood volume ( $p$ $<0.005 ; \mathrm{p}<0.01 ; \mathrm{p}<0.001)$.

3. There was a significant positive relationship between body length and heart rate $\mathrm{c}$ in horizontal, vertical positions and changes in heart rate when changing body position from horizontal to vertical $(r=0.50-0.71)$. There was also a positive significant relationship between body length and the value of systolic pressure in the vertical position $(\mathrm{r}=$ 0.72); negative significant relationship between body length and the value of the stroke volume of blood in the vertical position $(r=-0.65)$.

4. It was found that students with a body length over $190 \mathrm{~cm}$ have difficulty with vegetativevascular regulation. To improve the adaptive capacity of vegetative-vascular regulation to change the position of the body from horizontal to vertical, it is effective to use any exercise, but the most effective exercises that activate aerobic and anaerobic glycolytic energy supply systems. In addition, exercises that require frequent transitions from lying down (sitting) to standing position, as well as changes in the direction of movement are useful.

\section{Acknowledgments}

The study was conducted according to: research work, which is funded by the state budget of the Ministry of Education and Science of Ukraine for 2017-2018: "Theoretical and methodological foundations of the application of integrated technologies for self-improvement, harmonious 
physical, intellectual and spiritual development and the formation of a healthy lifestyle for people of different age and social groups, including athletes and people with special needs" (State Registration No: 0119U100616).

\section{Conflict of interest}

The authors declare that there is no conflict of interest.

\section{References}

1. Osadchiy LI. Body position and regulation of blood circulation. Naukka, 1982: 144p .

2. Kozina ZhL, Slyusarev VF, Volkov EP. The effectiveness of the development of non-traditional forms of autogenous training for the renewal of educational performance. Pedagogy, psychology and medical and biological problems in sports, 2001; 14:815.

3. Kozina ZhL, Slyusarev VF. The influence of the use of medicinal plants and mummy on some indicators of the autonomic nervous and vegetative-vascular systems of highly qualified basketball players, Pedagogy, psychology and medical and biological problems in sports, 2002;11:81-89.

4. Kozina ZhL, Slyusarev VF, Kryvich IP. The effectiveness of the use of mummy and pollen to improve performance and treatment of the musculoskeletal system of basketball players. Pedagogy, psychology and medical and biological problems of physical education and sports, 2001;15: 37.

5. Kozina ZhL, Slyusarev VF, Tugay D. Influence of non-traditional psychological-pedagogical and medico-biological methods of recovery on the functional state of young basketball players 11-12 years. Theory and practice of physical education, 2002;2: 35-44.

6. Kozina ZhL, Slyusarev VF. Unconventional methods of improving the efficiency of basketball players. Physical Education, Sports and Health Culture in Modern Society, 2002; 2: 199-201.

7. Kozina ZhL, Slyusarev VF Influence of a complex system of recovery on the level of special physical fitness and game performance of high-class basketball players. Pedagogy, psychology and medical and biological problems of physical education and sports, 2002;12:42-51.

8. Kozina ZhL, Vaksler MA, Tikhonova AO, Shchedriva LV. Peculiarities of special physical and functional training of basketball players of different game roles, Pedagogy, psychology and medical and biological problems in sports 2002; 6: 347-350.

9. Buhr LK, Stack CI, Luetkemeier MJ. The Effects Of Hydration Status On Pulse Rate And Heart Rate Variability During A Stand Test Of Orthostatic Tolerance. Medicine and Science in Sports and Exercise. 2013;45(5):37-.

10. Hynynen E, Iglesias X, Feriche B, Calderon C, Abalos X, Vazquez J, et al. Heart Rate Variability in Orthostatic Test During Different Training Periods in
Elite Swimmers. Medicine and Science in Sports and Exercise. 2012;44:782-

11. Kubala P, Smorawinski J, Kaciuba-Uscilko H, Nazar K, Bicz B, Greenleaf JE. Effect of three day bedrest on circulatory and hormonal responses to active orthostatic test in endurance trained athletes and untrained subjects. Journal of gravitational physiology : a journal of the International Society for Gravitational Physiology. 1996;3(2):40-1.

12. Rodrigues GD, Goncalves TR, De Souza SC, Da Silva Soares PP. Comparison of Cardiac Vagal Modulation From the Orthostatic Stress Test Between Untrained Individuals and Athletes. Medicine and Science in Sports and Exercise. 2014;46(5):341-2.

13. Rodriguez FA, Iglesias X, Feriche B, Calderon C, Abalos X, Vazquez J, et al. Effects of Altitude Training on Heart Rate Variability in Orthostatic Test in Elite Swimmers. Medicine and Science in Sports and Exercise. 2012;44:364-.

14. Vesterinen V, Nummela A. Nocturnal Heart Rate Variability and Morning Orthostatic Test as Tools to Monitor Training Load. Medicine and Science in Sports and Exercise. 2018;50(5):118-9.

15. Pavy-Le Traon A, Sigaudo D, Vasseur P, Maillet A, Fortrat JO, Hughson RL, et al. Cardiovascular responses to orthostatic tests after a 42-day head-down bed-rest. European Journal of Applied Physiology. 1998;77(1-2):50-9.

16. Lutfullin II, Al'metova RR. Heart rate variability in young hockey players at rest and during active orthostatic test. Fiziologiia cheloveka. 2014;40(2):105-11.

17. Schafer D, Olstad BH, Wilhelm M. Can Heart Rate Variability Segment Length During Orthostatic Test Be Reduced To 2 Min? Medicine and Science in Sports and Exercise. 2015;47(5):48-

18. Wolthuis RA, Hull DH, Fischer JR, McAfoose DA, Curtis JT. Blood-pressure variability of the individual in orthostatic testing. Aviation Space and Environmental Medicine. 1979;50(8):774-7.

19. Roberson KB, Signorile J, Singer C, Jacobs K, Eltoukhy M, Ruta N, et al. Hemodynamic Responses to an Exercise Stress Test in Parkinson's Disease Patients without Orthostatic Hypotension. Medicine and Science in Sports and Exercise. 2019;51(6):292-

20. Murray RH, Bowers JA, Goltra ER. Comparison of footboard and saddle supports for orthostatic tests on a tilt table. Journal of applied physiology. 1966;21(4):1409-11. 


\section{Information about the authors}

\section{Borysenko I.V.}

irynaborysenko13@gmail.com

H. S. Skovoroda Kharkiv National Pedagogical University

Alchevskikh st. 29, Kharkiv, 61002, Ukraine

\section{Cretu Marian}

https://orcid.org/0000-0003-1934-0534

cmaryan_mc@yahoo.com

Faculty of Science, Physical Education and Informatics; University of Pitesti

Str. Targul din Vale, nr.1, 110040 Pitesti, Arges, Romania

\section{Kozina Zh.L.}

http://orcid.org/0000-0001-5588-4825

zhanneta.kozina@gmail.com

H. S. Skovoroda Kharkiv National Pedagogical University

Alchevskikh st. 29, Kharkiv, 61002, Ukraine

\section{Інформація про авторів}

\section{Борисенко I.B.}

irynaborysenko13@gmail.com

Харківський національний педагогічний університет імені Г.С. Сковороди вул. Алчевських, 29, м. Харків, 61002, Україна

\section{Крету М.}

https://orcid.org/0000-0003-1934-0534

cmaryan_mc@yahoo.com

Факультет науки, фізичного виховання та інформатики, Університет Пітесті

Ул.Таргундін Вале, 1, 110040, Пітесті, Румунія

\section{Козіна Ж.Л.}

http://orcid.org/0000-0001-5588-4825

zhanneta.kozina@gmail.com

Харківський національний педагогічний університет імені Г.С. Сковороди

вул. Алчевських, 29, м. Харків, 61002, Україна

\section{Информация об авторах}

\section{Борисенко И.В.}

irynaborysenko13@gmail.com

Харьковский национальный педагогический университет имени Г.С. Сковороды ул. Алчевских 29, Харьков, 61002, Украина

\section{Крету М.}

https://orcid.org/0000-0003-1934-0534

cmaryan_mc@yahoo.com

Факультет науки, физического воспитания и информатики, Университет Питести

Ул.Таргундин Вале, 1, 110040, Питести, Румыния

\section{Козина Ж.Л.}

http://orcid.org/0000-0001-5588-4825

zhanneta.kozina@gmail.com

Харьковский национальный педагогический университет имени Г.С. Сковороды ул. Алчевских 29, Харьков, 61002, Украина

This work is licensed under a Creative Commons Attribution 4.0 International License (CC BY 4.0) 